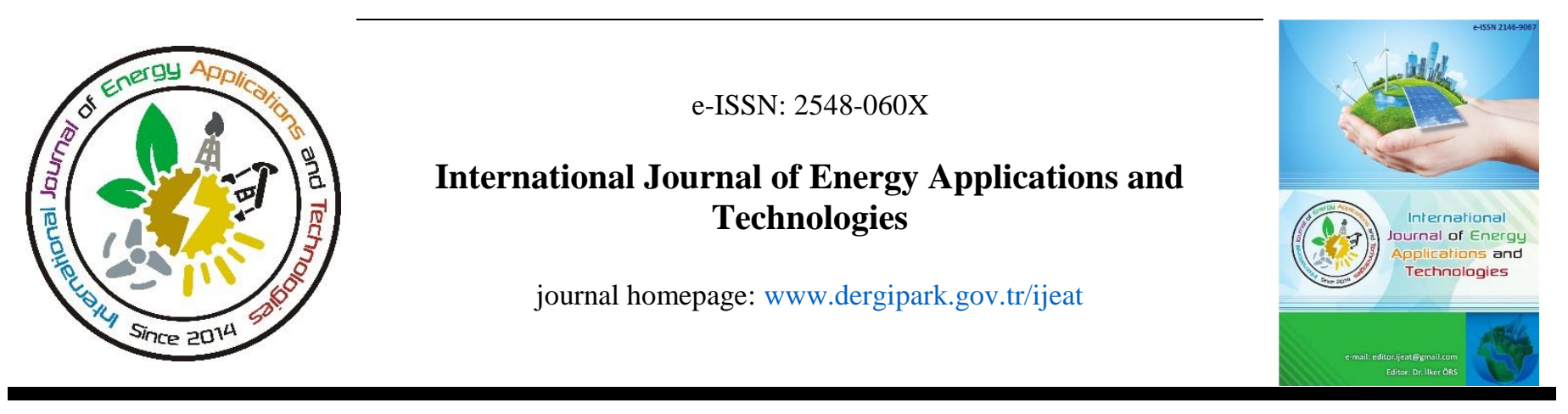

Original Research Article

\title{
A factorial analysis on the built-in risks influencing marginal oil field development in Nigeria
}

\author{
Samuel Ayodeji Omotehinse \\ Research Scholar, Department of Production/Industrial Engineering, University of Benin, Benin City, Edo State, Nigeria
}

\author{
ARTICLE INFO \\ * Corresponding author \\ drsamayodeji@gmail.com \\ Received July 24, 2020 \\ Accepted September 29, 2020 \\ Published by Editorial Board \\ Members of IJEAT \\ (C) This article is distributed by \\ Turk Journal Park System under \\ the CC 4.0 terms and conditions. \\ doi: 10.31593/ijeat. 773243
}

\begin{abstract}
Marginal field development in the prolific Niger Delta environment is of strategic importance to the Federal Government of Nigeria's drive towards aggressive reserve and production capacity enhancement. For successful development of a marginal field, it is imperative to understand the various risks and uncertainties that are inherent in developing the field as the oil industry is exposed to a lot of risk more than most manufacturing industries in the world. This study offers clarification and deep intuition about the insidiousness of these risk factors, discusses their wider implications and gives justification for their economic significance. This study investigates a total of thirty-four (34) risk variables influencing marginal oil field development by using a survey approach involving the use of Kendall's Coefficient of Concordance (KCC) and Principal Component Analysis (PCA). The Kendall's Coefficient of Concordance (KCC) analyzed the level of agreement among the 13 Judges who ranked the variables in descending order of importance. The result showed an index of agreement in ranking among the judges as $W=0.60$. This indicates $60 \%$ agreement among the Judges. The Principal Component Analysis (PCA) facilitated by StatistiXL software package was efficient in achieving parsimony in factor reduction from thirty-four variables to mere six factors. The result shows that six principal factors, creatively labelled: Geo-technical Economism, Operational and Economic Leaven, Fiscal Ripple, Bottom Line, Logistics and Oil quality represent the principal risk factors that influence marginal oil field development in Nigeria. This study brings to bear the militating factors that affect operations and profitability of marginal oilfields development in Nigeria.
\end{abstract}

\section{Introduction}

A lot of oil field developments are ongoing in the Niger-Delta because several marginal fields have been given out to investors in addition to others that are on the verge of being given to indigenous investors. If investors are unaware of the risks and uncertainty they are bound to encounter while developing these fields, it is likely that they end up with negative cash flows due to poor investment decisions. Evaluation and quantification of risks and uncertainties are therefore necessary. This will however not reduce the risk to be faced by the investor, but this will help in decision making and point towards the right choice of risk to be taken. Several years after the awards of marginal fields to investors, only a few of the awardees have been able to have a successful oil production. This is owed to innumerable challenges that marginal field investors have faced over the years and these challenges were not properly planned for. It is imperative to note that the most important aspect of any field development planning exercise is inherent in adequately quantifying risks and uncertainty, particularly when information availability is limited. Issues in the development of marginal oilfields in 
Nigeria was reported by [1]. The study examined the controversy surrounding the development of marginal oilfields in Nigeria as well as the legal framework for the development of marginal oilfields. Kue and Orodu [2] considered the economic analysis of innovative approaches to marginal field development while [3] assessed the relevance and challenges of corporate social responsibility with emphasis on sustainable development policies for economic development of marginal oil fields in Niger Delta. According to Oroma [4] financing of oil and gas development in Nigeria is a major factor militating against the development of marginal fields. Other notable researches includes: the assessment of local content policy and its implications on the operation of marginal oil fields and the Nigeria economy by [5]. Factors influencing the optimization of natural gas from marginal oil field operations in Nigeria was also investigated by [6]. The study revealed that provision of adequate infrastructure and collaboration are some of the critical success factors, while barriers to optimization of natural gas are inadequate funding, monopolistic market structure, weak manufacturing and inadequate linkages. Similar studies consist of [7-10]. Others are: [11-12].

Extensive literature exist on the various approaches to handling risks in projects but very few studies appear to have addressed risks in marginal oil fields. Some of the techniques for general risk management that concern the use of simulation is given by [13-19]. Other statistical approach employed to study risk in project management includes: [2023] as well as [24]. Related studies include [22-28]. It is evident from the reviewed literature that a dearth of research exist on the statistical analysis of inherent risks in marginal oil field development which this study seeks to address. The aim of this study is to identify a wide range of variables that influence risks in marginal oil fields using Kendall's Coefficient of Concordance to classify them in descending order of importance and Principal Component Analysis to enable a data summary and reduction into fewer dimensions.

\section{Materials and Methods}

\subsection{Materials}

The data used in this study involved the thirty-four (34) risk variables identified through a wide literature survey. These variables were used to craft questionnaires that were administered to respondents for their expert evaluation.

\subsection{Methods}

\subsubsection{Kendall's coefficient of concordance (KCC)}

Thirty-four (34) risk variables that influence the marginal oil field development were identified through a wide literature survey. The merit order of these variables was statistically analyzed by the use of Kendall Coefficient of Concordance (W) that required 13 Judges to provide an ordinal scale ranking of the variables. The Judges were drawn from a homogenous set of professionals and practicing managers in the oil and gas industry. The variables were used to craft questionnaires that were administered to knowledgeable respondents (Judges) who ranked the variables in merit order of sequentiality. The crafting of the questionnaire was done with Rensis Likert's 5-point attitudinal scale. The measure of agreement among the judges was computed. Chi square $\left(X^{2}\right)$ was used to appraise how consistent the judges were in ranking the scale items.

\section{Test of Hypothesis:}

The $X^{2}$ - test that guided the application of hypotheses include:

$H_{0}$ : Judges ranking are discordant

$H_{1}$ : Judges ranking are consistent

Decision Rule: if $X_{c a l}^{2}>X_{t a b}^{2}$, we reject the null hypothesis, $H_{0}$.

If $X_{c a l}^{2}<X_{t a b}^{2}$, we accept the null hypothesis, $H_{0}$.

The Kendall coefficient of concordance is given by

$W=\frac{S}{\frac{1}{2} K^{2}\left(N^{3}-N\right)}$

where,

$S=\sum\left(\frac{\sum R_{j}}{N}\right)^{2}$

$\mathrm{R}_{\mathrm{j}}=$ Column sum of ranks

$\mathrm{N}=$ Total number of Variables

$\mathrm{S}=$ Variance

$\mathrm{K}=$ Number of Judges

The ranking by the judges were polled to obtain a sequence of well-ordered scale items.

\subsubsection{Determination of principal component analysis} (PCA)

The 34 critical variables identified from literature were used to craft another set of questionnaires that was administered to hundred (100) respondents for their expert evaluations. Out of the 100 set of the questionnaire administered only 60 were retrieved. The level of agreement among the respondents were scaled with 5-point Rensis Likert's attitudinal scale. Table 1 depict the 5-point Rensis Likert's response options employed in this study.

Table 1. Rensis-Likert's scale 5-point response option

\begin{tabular}{clc}
\hline S/NO & RESPONSE OPTION & WEIGHT ASSIGNED \\
\hline $\mathbf{1}$ & Completely-Agree & 5 \\
$\mathbf{2}$ & Agree & 4 \\
$\mathbf{3}$ & Undecided & 3 \\
$\mathbf{4}$ & Disagree & 2 \\
$\mathbf{5}$ & Completely-Disagree & 1 \\
\hline
\end{tabular}

The respondent's scores were collated to form a data matrix that was input into StatistiXL software where the following outputs were gotten: varimax rotated factor loadings, correlation matrix, eigenvalues, descriptive Statistic, eigenvector, case-wise factor scores, explained variance and factor plot and unrotated factor loading. Table 2 shows the compilation of the identified risk variables. 
Table 2. Risk variables influencing marginal oil field

\begin{tabular}{llll}
\multicolumn{3}{c}{ development } \\
\hline S/N & Risk variables & S/N & Risk variables \\
\hline 1 & Economic Factor & 18 & Reservoir characteristics \\
2 & Fiscal Regime & 19 & Government regulation \\
3 & Government Policy & 20 & Operator equipment \\
4 & Capital Constrain & 21 & Venture capitalist \\
5 & Size & 22 & Reservoir damage \\
6 & Remoteness of Oil-Field & 23 & Logistics \\
7 & Complexity of Operation & 24 & Political instability \\
8 & Aging Field & 25 & Production schedule \\
9 & Reserve Depletion & 26 & Strategic element \\
10 & Tumbling oil prices & 27 & Evolution in technology \\
11 & Geographical location & 28 & Oil price \\
12 & Energy demand & 29 & Economic uncertainty \\
13 & Hydrocarbon charge & 30 & Geological concept \\
14 & Economic evaluation & 31 & Volatile commodity \\
15 & Infrastructure & 32 & Demand and supply \\
16 & Oil quality & 33 & Health safety \\
17 & Operational cost & 34 & Environmental pressure \\
\hline
\end{tabular}

\section{Result and Discussion}

The results of this study are presented in the following sequence:

\subsection{Result of Kendall Coefficient of concordance (KCC)}

From the factor ranking matrix, $\mathrm{S}=338802.506$

$\mathrm{K}=$ Number of judges $=13$

$\mathrm{N}=$ Number of factors being ranked $=34$
Inputting the above values into equation 1 , we have

$W=\frac{338802.56}{\frac{18^{2}}{12}\left(34^{3}-34\right)}=\frac{338802.56}{553051.191}=0.6$

The Kendall's coefficient of concordance $W=0.6$ which is at the threshold of substantial.

Also, $X_{\text {cal }}^{2}=K(N-1) W$

where, $\mathrm{K}=13, \mathrm{~N}=34, \mathrm{~W}=0.6$

$X_{\text {cal }}^{2}=13(34-1) 0.6=257.40$

Since $X_{c a l}^{2}=257.40>X_{t a b}^{2}=52.1914$ the null hypothesis, $\mathrm{H}_{\mathrm{o}}$ was rejected at a p-value of 0.05 , implying that the judges were consistent in their ranking of the thirty-four risk variables.

\subsection{Result of Principal Component Analysis (PCA)}

The scree plot obtained from the StatistiXL analysis depicted in Figure 1 displayed the elbow at $(6,1)$. It is therefore evident from the scree plot that at eigenvalue of 1 , and component number 6 , the curvity tends to flatten out which advocate that the six factors extracted are appropriate. This shows that there is substantial parsimony in factor reduction. Figure 2 indicate the corresponding factor plot.

The result of the varimax rotated factor matrix is depicted in Table 3 followed by the factors interpretation.

Table 3. Varimax rotated factor loadings for marginal oil field production

\begin{tabular}{|c|c|c|c|c|c|c|c|}
\hline & Variable & Factor 1 & Factor 2 & Factor 3 & Factor 4 & Factor 5 & Factor 6 \\
\hline 1 & Economic Factor & 0.679 & 0.446 & 0.356 & 0.310 & 0.253 & 0.140 \\
\hline 2 & Fiscal Regime & 0.671 & 0.486 & 0.236 & 0.296 & 0.162 & 0.175 \\
\hline 3 & Government Policy & 0.635 & 0.397 & 0.362 & 0.405 & 0.193 & 0.133 \\
\hline 4 & Capital Constrain & 0.427 & 0.443 & 0.395 & 0.347 & 0.382 & 0.060 \\
\hline 5 & Size & 0.431 & 0.674 & 0.413 & 0.241 & 0.247 & 0.122 \\
\hline 6 & Remoteness of Oil-Field & 0.478 & 0.689 & 0.345 & 0.272 & 0.068 & 0.124 \\
\hline 7 & Complexity of Operation & 0.487 & 0.667 & 0.333 & 0.290 & 0.122 & 0.246 \\
\hline 8 & Aging Field & 0.569 & 0.416 & 0.457 & 0.387 & 0.182 & 0.184 \\
\hline 9 & Reserve Depletion & 0.568 & 0.679 & 0.221 & 0.318 & 0.109 & 0.045 \\
\hline 10 & Tumbling oil prices & 0.326 & 0.347 & 0.755 & 0.391 & 0.148 & 0.066 \\
\hline 11 & Geographical location & 0.494 & 0.604 & 0.334 & 0.286 & 0.279 & 0.113 \\
\hline 12 & Energy demand & 0.640 & 0.288 & 0.316 & 0.380 & 0.362 & 0.076 \\
\hline 13 & Hydrocarbon charge & 0.293 & 0.209 & 0.274 & 0.865 & 0.169 & 0.061 \\
\hline 14 & Economic evaluation & 0.391 & 0.527 & 0.419 & 0.506 & 0.097 & 0.156 \\
\hline 15 & Infrastructure & 0.522 & 0.552 & 0.329 & 0.169 & 0.230 & 0.141 \\
\hline 16 & Oil quality & 0.484 & 0.494 & 0.375 & 0.089 & 0.274 & 0.533 \\
\hline 17 & Operational cost & 0.288 & 0.429 & 0.404 & 0.675 & 0.182 & 0.031 \\
\hline 18 & Reservoir characteristics & 0.753 & 0.428 & 0.316 & 0.235 & 0.124 & 0.220 \\
\hline 19 & Government regulation & 0.420 & 0.654 & 0.500 & 0.269 & 0.167 & 0.129 \\
\hline 20 & Operator equipment & 0.808 & 0.328 & 0.176 & 0.297 & 0.157 & -0.021 \\
\hline 21 & Venture capitalist & 0.840 & 0.347 & 0.246 & 0.215 & 0.175 & 0.055 \\
\hline 22 & Reservoir damage & 0.405 & 0.628 & 0.366 & 0.332 & 0.312 & 0.146 \\
\hline 23 & Logistics & 0.485 & 0.292 & 0.209 & 0.406 & 0.664 & 0.133 \\
\hline 24 & Political instability & 0.756 & 0.315 & 0.351 & 0.179 & 0.298 & 0.169 \\
\hline 25 & Production schedule & 0.514 & 0.692 & 0.225 & 0.333 & 0.201 & 0.070 \\
\hline 26 & Strategic element & 0.479 & 0.571 & 0.234 & 0.343 & 0.360 & 0.165 \\
\hline 27 & Evolution in technology & 0.318 & 0.366 & 0.702 & 0.423 & 0.142 & 0.158 \\
\hline 28 & Oil price & 0.517 & 0.509 & 0.248 & 0.492 & 0.256 & 0.105 \\
\hline 29 & Economic uncertainty & 0.420 & 0.654 & 0.500 & 0.269 & 0.167 & 0.129 \\
\hline 30 & Geological concept & 0.647 & 0.414 & 0.357 & 0.314 & 0.119 & 0.349 \\
\hline 31 & Volatile commodity & 0.338 & 0.593 & 0.574 & 0.253 & 0.242 & 0.084 \\
\hline 32 & Demand and supply & 0.691 & 0.458 & 0.295 & 0.351 & 0.191 & 0.089 \\
\hline 33 & Health safety & 0.549 & 0.438 & 0.514 & 0.270 & 0.108 & 0.213 \\
\hline 34 & Environmental pressure & 0.332 & 0.607 & 0.394 & 0.419 & 0.281 & 0.138 \\
\hline
\end{tabular}




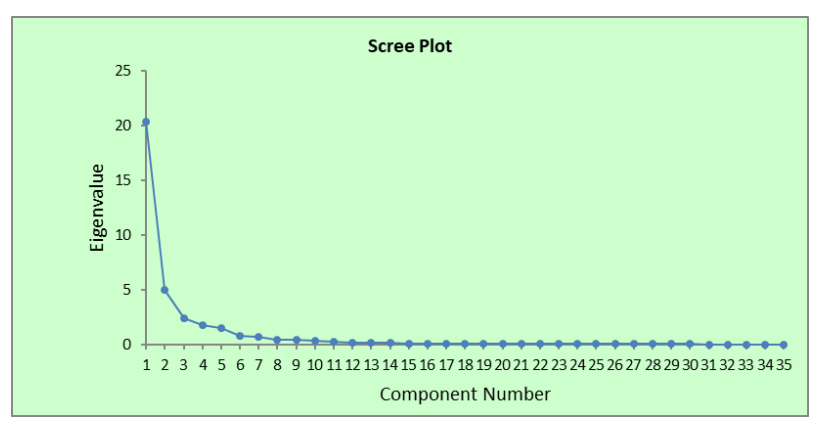

Fig. 1. Scree plot

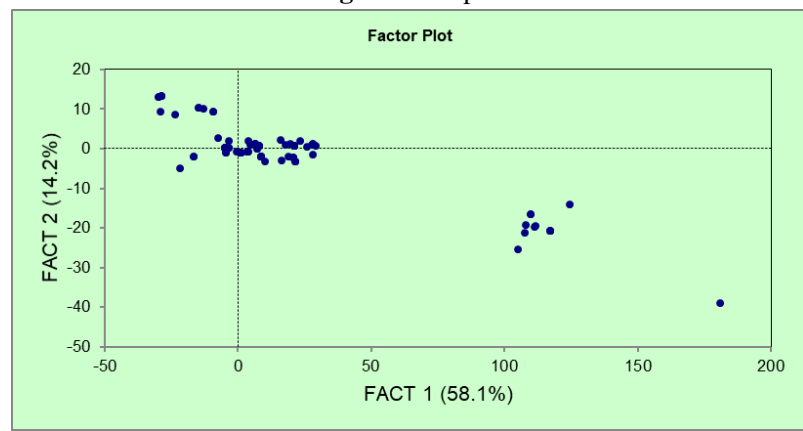

Fig. 2. Factor plot

\subsubsection{Creative labeling of the six factors}

The PCA model adopted was successful in sizably reducing the 34 variables to mere 6 factors, a parsimony that can enhance policy development.

Table 4. Factor $1\left(\mathrm{~F}_{1}\right)$ - Geo-technical economism

\begin{tabular}{clc}
\hline $\begin{array}{c}\text { Variable } \\
\text { number }\end{array}$ & $\begin{array}{l}\text { Variable } \\
\text { description }\end{array}$ & $\begin{array}{c}\text { Factor } \\
\text { loading }\end{array}$ \\
\hline 1 & Economic Factor & 0.679 \\
2 & Fiscal Regime & 0.671 \\
3 & Government Policy & 0.635 \\
8 & Aging Field & 0.569 \\
12 & Energy demand & 0.640 \\
18 & Reservoir characteristics & 0.753 \\
20 & Operator equipment & 0.808 \\
21 & Venture capitalist & 0.840 \\
24 & Political instability & 0.756 \\
28 & Oil price & 0.517 \\
30 & Geological concept & 0.647 \\
32 & Demand and supply & 0.691 \\
33 & Health safety & 0.549 \\
\hline
\end{tabular}

The first factor $\left(\mathrm{F}_{1}\right)$ shown in Table 4 , creatively labeled Geotechnical Economism, clustered 13 variables, all wielding positive factor loadings simplifying that it is a sturdy or stocky factors. This is a principal factor containing two lead variables namely: venture capitalist and operator equipment with associated factor loading of 0.840 and 0.808 respectively. The ventures capitalist, indeed, is a risk-taker and is ever willing to take a leap in there appears to be profit prospects in the field of investment. Again, operator's equipment is vital for oil and gas exploration and production. And that is basically the reason for its substantial factor loading of 0.808 . Next in the order of significant variables are political instability and reservoir characteristics. The first variable political instability could affect lease agreement regarding oil blocks especially in Nigeria where offer are made based on political consideration when a new party comes to power, it can reverse earlier decisions in block allotments. This brings in the concept of risk. Political instability has a factor loading of 0.756. On the hand, reservoir characteristic is an important consideration in marginal fields. They include the nature of the reservoir like: Permeability, Viscosity, Formation volume factor, Porosity, Formation pressure, Gas/oil ratio, Compressibility and Reservoir depth. Next are the following variables: demand and supply, economic factor, fiscal regime, geological concept, energy demand, government policy. They wield the factor loadings of $0.691,0.679,0.671,0.640$, and 0.6735 respectively. The first in this series is demand and supply, which implies that once an oil field has been built, the increase in demand for oil has the same effect as reduction in supply. Some of the major factors affecting marginal field development include also low level of support of infrastructure funding constraints, high operational and capital expenditure, institutional frame work and insufficient policy. Favorable fiscal regime with factor loading 0.671 contributes immensely to the rapid development of marginal field program. Geological concept with factor leading 0.647 has to do with the location of the reservoir. Next is fluctuating energy demand resulting from diversification into renewable sources leading to the low demand for oil resulting to lower oil prices. Government policy with factor loading 0.635 has an impact on decision making in acquiring a marginal field since some action plan from government could favour or disfavour marginal field acquisition. Ageing oil field: this is old oil field that had being producing for a very long time and may be having a very low production rate or may require more capital to bring it back to life. Health safety and environment showed that the location of some oil field may be highly unsafe for operational works and could discourage investors. Oil price is always in the known by most investors, but it is not stable which could be favorable and most times cannot be predicted.

Table 5. Factor $2\left(\mathrm{~F}_{2}\right)$ - Operational and economic leaven

\begin{tabular}{clc}
\hline $\begin{array}{c}\text { Variable } \\
\text { number }\end{array}$ & $\begin{array}{l}\text { Variable } \\
\text { description }\end{array}$ & $\begin{array}{c}\text { Factor } \\
\text { loading }\end{array}$ \\
\hline 4 & Capital Constrain & 0.443 \\
5 & Size & 0.674 \\
6 & Remoteness of Oil-Field & 0.689 \\
7 & Complexity of Operation & 0.667 \\
9 & Reserve Depletion & 0.679 \\
11 & Geographical location & 0.604 \\
14 & Economic evaluation & 0.527 \\
15 & Infrastructure & 0.552 \\
19 & Government regulation & 0.654 \\
22 & Reservoir damage & 0.628 \\
25 & Production schedule & 0.692 \\
26 & Strategic element & 0.571 \\
29 & Economic uncertainty & 0.654 \\
31 & Volatile commodity & 0.593 \\
34 & Environmental pressure & 0.607 \\
\hline
\end{tabular}


This regime creatively labeled operational and economic leaven clustered 15 risk variables. The variable with the highest factor loading is Production schedule, with 0.692 . This is the lineup of activities with respect to the output or yield from the field in question. Next is remoteness of oil field with factor loading of 0.689 which talks about an oil field that is located far away in an isolated area from near social amenities, and will cost investor more to bring in such needed amenities. Reserve depletion with factor loading 0.679 has to do with the emptying, exhaustions or reduction of hydrocarbon reserve in oil field over a long period of time. Size of field with 0.674 factor loading simply identify with the dimension or measurement of the field which can influence the quantity of hydrocarbon in the reservoir. Complexity of operation with the factor loading 0.667 has to do with the intricacy or complication in series of actions or processes in the field of operation and if high could discourage investors. Economic uncertainty having factor loading 0.654 talks about a state of financial or commercial instability which cannot be predicted but could pose risk for marginal field investors. Government regulation with the same factor loading as 0.654 or equal importance with economic uncertainty as regards this study simply implies to the political control of the rules, statue or law in managing or acquiring marginal field which can favor investors today and disfavor them tomorrow. Reservoir damage having factors loading of 0.628 has to do with extent of destruction inside the reservoir which will eventually cost more to carry out work over jobs. Environmental pressure with factor loading 0.607 has to do with the issue that are of troublesome matters related to the environment, they are of burden to the field process (community relations). Geographical location with factor loading 0.604 simply describe the position, site, spot, location where the field is been situated on the earth surface, which could be an advantage or disadvantage to operational work on marginal field. Volatile commodity with factor loading 0.593 has to do with the product which could be oil product that can easily vaporize or explode easily and can cause losses during haulage after production. Strategic element having factor loading 0.571 has to do with certain design or plans extremely importance to achieve a set of goal. If not proper arranged could cost investors some fortune. Infrastructure with factor loading of 0.552 refers to the foundational or underlying features of an operation which is very essential. Economic evaluation with factor loading of 0.527 simply means the effort outlaid, the worth been appraise that will give a good return for money invested. Capital constrain with factor loading 0.443 has an impact on marginal field acquisition because if investors do not have what it takes to acquire and operate the field, interest will not be there.

Under fiscal ripple, only two variables namely tumbling oil price and evolution in technology clustered with factor loading 0.755 and 0.702 respectively. The tumbling oil prices refers to the disorderly state or tossing about of oil prices in the world market which can send confusing signals to investors. While that of evolution in technology with factor loading 0.702 deals with changes, development progression or methods and process in solving problems which can affect marginal field acquisition because what might be on ground on the field of operation may be absolute and requires getting the latest technology which may be more expensive to operate and acquire.

Table 6. Factor $3\left(\mathrm{~F}_{3}\right)$ - Fiscal ripple

\begin{tabular}{clc}
\hline $\begin{array}{c}\text { Variable } \\
\text { number }\end{array}$ & \multicolumn{1}{c}{$\begin{array}{c}\text { Variable } \\
\text { description }\end{array}$} & $\begin{array}{c}\text { Factor } \\
\text { loading }\end{array}$ \\
\hline 10 & Tumbling oil prices & 0.755 \\
27 & Evolution in technology & 0.702 \\
\hline
\end{tabular}

Table 7. Factor $4\left(\mathrm{~F}_{4}\right)$ - Bottom line

\begin{tabular}{ccc}
\hline $\begin{array}{c}\text { Variable } \\
\text { number }\end{array}$ & $\begin{array}{c}\text { Variable } \\
\text { description }\end{array}$ & $\begin{array}{c}\text { Factor } \\
\text { loading }\end{array}$ \\
\hline 13 & Hydrocarbon charge & 0.865 \\
17 & Operational cost & 0.675 \\
\hline
\end{tabular}

Variables description under bottom line are hydrocarbon charge and operational cost both having factor loading 0.865 and 0.675 . The word bottom line simply means the most important thing to consider and it is observed that hydrocarbon charge has the highest factor loading under this regime with 0.865 which reveals to us that it is of the utmost significance to all the variable descriptions. This is so because what the investors are looking for to produce is the hydrocarbon in the reservoir. And if it is loaded with enough hydrocarbons simply means the investors will have more money in return on investment. Operational cost with factor loading 0.675 refers to the expenditure on running of the marginal field to the selling point of the product. This is an aspect investor will also consider before acquiring a marginal field to ascertain profit making possibilities.

Table 8. Factor $5\left(\mathrm{~F}_{5}\right)$ - Logistics

\begin{tabular}{ccc}
\hline $\begin{array}{c}\text { Variable } \\
\text { number }\end{array}$ & $\begin{array}{c}\text { Variable } \\
\text { description }\end{array}$ & $\begin{array}{c}\text { Factor } \\
\text { loading }\end{array}$ \\
\hline 23 & Logistics & 0.664 \\
\hline
\end{tabular}

Logistics which is a lone variable under this factor has a positive factor loading of 0.664 and has its significance in marginal field exploration because both personnel and equipment need to be transported to and fro the field to actualize hydrocarbon production. And considering offshore and onshore marginal field, they have far different mode and expense on logistic. This definitely will affect decision making in marginal field acquisition.

Oil quality is also a lone factor, the sixth in the making of the variables factors and the last, but it is of great importance because the quality of the crude oil in the world market is of great significance. We have oil that is sweet and sour. This 
means the sweet crude or sweet Hydrocarbon has lesser sulfur content compare to sour crude. Which in-turn, will affects their prices in the market and definitely has effect on the marginal field risk analysis.

Table 9. Factor $6\left(\mathrm{~F}_{6}\right)$ - Oil quality

\begin{tabular}{ccc}
\hline $\begin{array}{c}\text { Variable } \\
\text { number }\end{array}$ & $\begin{array}{c}\text { Variable } \\
\text { description }\end{array}$ & $\begin{array}{c}\text { Factor } \\
\text { loading }\end{array}$ \\
\hline 16 & Oil quality & 0.533 \\
\hline
\end{tabular}

\section{Conclusion}

The result of this study has spelled out issues relating to risk in marginal oilfield development in Nigeria. The focus of the study was centered on the use of principal component analysis and Kendall's coefficient of concordance to analyze the thirty four risk variables associated with marginal oil field production extracted from wide literature survey conducted. The Kendall's Coefficient of Concordance (KCC) model helped to analyze the level of agreement among the knowledgeable respondents who ranked the variables in descending order of importance with the chi square providing the significance level at which the coefficient of concordance (W) was adjudged as acceptable or otherwise. The Principal Component Analysis (PCA) model adopted was effective in achieving parsimony in factor reduction from thirty-four variables to mere six factors. The result shows that six principal factors, creatively labelled: Geotechnical Economism, Operational and Economic Leaven, Fiscal Ripple, Bottom Line, Logistics and Oil quality represent the principal risk factors that influence marginal oil field development in Nigeria and, in addition, provided insight into their merit order of importance and the way the variables interplay. This will aid investors who desires to engage in marginal oilfield operation in Nigeria as well as help any operator or government to visualize the extent of risk that is embedded in marginal oilfields.

\section{ORCID}

S. Ayodeji Omotehinse

0000-0002-5036-0800

\section{References}

[1] Atsegbua, L. 2005. Issues in the Development of Marginal Oilfields in Nigeria. Journal of Energy \& Natural Resources Law. 23:3, 323-336, DOI: 10.1080/02646811.2005.11433408.

[2] Kue, Y.N. and Orodu, O.D. 2006. Economic Analysis of Innovative Approaches to Marginal Field Development. Paper presented at the $30^{\text {th }}$ Annual SPE international Technical Conference and Exhibition in Abuja, Nigeria, July31-August 2.

[3] Oruwari, H.O. 2016. Sustainable Corporate Social Responsibility in the Development of Marginal Oil
Fields in Niger Delta. International Journal of Innovative Research and Development. Vol. 5 Issue 4. Pp. 36-42.

[4] Oroma, O.J. 2006. What are the legal and contractual implications of the $40 \%$ cap on foreign equity participation in Nigeria marginal fields? Available from:

www.dundee.ac.uk/cepmlp/gateway/files.php?file $=\mathrm{CA}$ R-11_1...pdf (accessed on 12 April 2011)

[5] Oruwari, H.O. and Dosunmu, A. 2016. Local Content Policy and Its Implications on Marginal Oil Fields Operations and the Nigerian Economy. International Journal of Innovative Research and Development. Vol. 5 Issue 6. Pp. 354-360.

[6] Oruwari, H.O. and Dosunmu, A. 2016. Optimum Utilization of Natural Gas from Marginal Oil Fields in Nigeria. International Journal of Innovative Research and Development. Vol. 5 Issue 6. Pp. 361-369.

[7] Aldrich, J. 2000. Are Marginal Fields Worth the Effort?: An Examination of Past Efforts in Incentives and a Look Forward to Future Potential, paper presented at AAPG international conference, Bali, October, 2000.

[8] Offia, U. S. 2011. Development and Management of Marginal Oil Field in the Niger Delta Basin: Opportunities and Challenges. Petroleum Technology Development Journal. Vol. 1, July 2011.

[9] Egbogah, E.O. 2011. Onshore/Marginal Field Developments: Challenges, Opportunities and Prospects for the Future. presented at 2011 SPE Annual Oloiribi Lecture and Energy Forum, Lagos, Nigeria, June 30 .

[10] Akinwale, Y.O. and Akinbami, J.K. 2016. Economic Evaluation of Nigerian Marginal Oil and Gas Field using Financial Simulation Analysis. International Journal of Energy Economics and Policy, 6(3), 563574.

[11] Akinpelu, A.O. and Omole, O.A. 2009. Economics of Nigeria Marginal oil field. Identifying high impact variable. SPE paper no 106001: Nigeria annual international conference and exhibition. 3-5 August 2009, Abuja, Nigeria.

[12] Akinwale, Y.O. 2016. Harnessing Science Technology and Innovation for Enhancing Marginal Oil and Gas Field Development in Nigeria: A Comparative Analysis. International Journal of eBusiness and eGovernment Studies. Vol 8, No 2, 47-63.

[13] Kostetsky, O. 1994. A facilitated, graphics and Monte Carlo based predicted project process. Engineering Management Conference Proceedings, IEEE International Conference, pp: 177-184, ISBN: 0-78031955-9, CH3458-7194/0006, Indexed by IET Inspec. 
[14] Harbaugh, J.W., J.C. Davis and C. Wendebourg. 1995. Computing risk for oil prospects: Principles and programs. Computer Methods in the Sciences, Vol. 4, ISBN-10: 0080418902, Har/Dsk Edn., Pergamon Publishers.

[15] Chinbat, U. and Takakuwa, S. 2009. Using Simulation analysis for mining risk management project. Proceedings of the 2009 Winter Simulation Conference (WSC), Nagoya, Japan, pp: 2612-2623.

[16] Rose, P. 2001. Risk Analysis and Management of Petroleum Exploration Ventures. AAPG Methods in Exploration Series, No. 12, AAPG, USA.

[17] Jacinto, C.M.E. 2002. Optimal investment decisions for a set of projects under conditions of uncertainty. Discrete Event Simulation for the Risk of Development of an Oilfield. Proceedings of the Water Simulation Conference.

[18] Coelho, D.K. and Jacinto, C.M.C. 2005. Risk assessment of drilling and completion operations in petroleum wells using a Monte Carlo and a neural network approach. Proceedings of the 2005 Winter Simulation Conference, Institute of Electrical and Electronics Engineers, pp: 1892-1897.

[19] Jin, D., Wang, Z., Liu, X., Yang, J.M. and Han, M. 2010. Construction project schedule risk analysis and assessment using Monte Carlo simulation method. IEEE International Conference on Advanced Management Science (ICAMS), Nanjing, China, 1: 597601.

[20] Svenda, G.S., Kanjuh, S., Konjic, T. and Miranda, V. 2006. Using a Fuzzy Modeling in Decision Making for Planning Under Uncertainty with Risk Analysis Paradigm, IEEE Publication. 8th Seminar on Neutral Network Application in Electrical Energy, Nev Rel. Retrieved from: http:/ www. ewh. iee. org/reg/8/conferences.html, September

[21] Lingling, M., Liwen, C. and Ping, L. 2008. Real Estate Investment Risk Analysis Based on Fuzzy AHP. ISBN: 978-1-4244-2108-4/08/\$25.00 (C) 2008 IEEE.

[22] Jian-Wei, L.V. and Zhonghua, L. 2008. Research on dynamic evolvement analysis and modeling of risk in development of navy vessel. 4th International Conference on Wireless Communications, Networking and Mobile Computing, WiCOM '08, Wuhan, pp: 1-4.

[23] Wang, J.Q. and Sun, T. 2008. Fuzzy multiple criteria decision making method based on prospect theory. International Conference on Information Management, Innovation Management and Industrial Engineering, ISBN: 978-0-7695-3435- 0/08 \$25.00 (C) 2008 IEEE, DOI 10.1109/ICIII.2008.229.

[24] Petreska, B.R. and Kolemisevska-Gugulovska, T.D. 2010. A fuzzy rate-of-return based model for portfolio selection and risk estimation. IEEE International
Conference on Systems Man and Cybernetics (SMC), DOI: 10.1109/ICSMC.2010.5642278, pp: 1871-1877.

[25] Chinbat, U. and Takakuwa, S. 2009. Using Simulation analysis for mining risk management project. Proceedings of the 2009 Winter Simulation Conference (WSC), Nagoya, Japan, pp: 2612-2623.

[26] Adamu, M., Ajienka, J., Ikiensikimama, S. 2013. Economic analysis on the development of Nigerian offshore marginal fields using probabilistic approach. Advances in Petroleum Exploration and Development, 6(1), 11-21.

[27] Alaneme, C.E. and Igboanugo, A.C. 2013. A factorial study on the inherent risk of Nigerian Marginal oil fields. Research Journal of Applied Sciences, Engineering and Technology, 6(3): 468-476, 2013.

[28] Akinwale, Y. 2015. Empirical Analysis of Technology and Innovation Capabilities of the Indigenous Oil and Gas Firms Towards the Development of Oil Fields in Nigeria. A Paper Presented at NACETEM Seminar Series, No. 08/017. 